\title{
Conflict and Coordination of Democracy and Equality under Legal Construction in China
}

\author{
Yiyuan Niu \\ China University of Political Science and Law \\ Beijing, China 100088
}

\begin{abstract}
At present, in the development, democracy and equality are endowed with new, more advanced and more scientific meanings in China. They mean more extensive, more noble people's democracy, collective democracy and equality. The meaning of democracy and equality in the rule of law is different from that of sociology, economics and politics. The democracy in the sense of rule of law is reflected in the establishment of democratic political system and the enjoyment of democratic rights of citizens, while equality is expressed as that all people are equal before the law, that is, all Chinese citizens enjoy equal legal rights, induding political rights, right of the person and property rights. Between democracy and peace are harmony and unity as a main, but also occasionally there is an ine vitable conflict. Democracy and equality are a key part of legal construction and development, while the rule of law is the solution and guarantee to solve conflict between democracy and equality.
\end{abstract}

Keywords-democracy; equality; the rule of law; conflict

\section{INTRODUCTION}

Democracy was a political concept at the earliest, while equality was not the concept of legal system then. The both of them were an issue of study of sociology and anthropology made by different classes. However, along with the social development and economic prosperity, in different fields, both of them were endowed with other meanings outside political science. For example, democracy and equality in law were expressed to be "enjoy democracy and equality in term of political rights, personal rights and property rights" and "everyone is equal before the law". In the present development, the rule of law, democracy and equality in the field of political philosophy indeed runs ahead of us. These three ideas have created a profound impact on the construction of our modern social political system, economic system and legal system, but they have something different from those of the western capitalist countries in the context of the socialist construction of the rule of law.

In the analysis made in combination with the Marx's dialectics historical methodology, democracy, equality and the rule of law differ from history and culture. One relatively-successful development mode should not be used to negate the one of democracy which is developing and is conducive to the social development, and so to the other rest two concepts. At the same time, in combination with Professor Li Deshun's subject method theory, the consideration of the value judgment and the value for the object action on the subject is more important. The object's value differs from the subject. At present, there is no socalled universal value besides natural science in the world. This phenomenon can be attributed to the multiple values judgment standard and value choice caused by different subjects.

Therefore, the discussion of the relationship between democracy, equality and the rule of law shall be combined with the interests of the whole society and the people's interests, having in view not only the existing problems and difficulties, but also the particularity of democracy, equality and the rule of law in the China's special development stage. It is required, along with the times, to steadily push forward these three to common and harmonious development.

\section{A CONFLICT BETWEEN DEMOCRACY AND EQUALITY UNDERTHE BACKGROUND OF SOCIALISM RULE OF LAW}

At present, the thinking dilemma that democracy and equality are faced to is given as the following: first, blindly adore the western democracy, equality and idea of rule of law in the legal construction; second, thinking that as long as democracy and the rule of law are realized, equality is close at hand. In such a thinking predicament, the conflict between democracy and equality is mainly expressed in two aspects: first, the priority selection of instrumental value and purpose value; second, the realization form of democracy and the contradiction of equality.

\section{A. The Conflict Caused by Priority Selection of Instrumental Value and Purpose Value}

In the value choice, democracy and equality have a tendency to one side. In social practice, de mocracy prefers to the instrumental value, while equality is inclined to the purpose value.

The form of democracy is closely related to the economic form of society, the nature of the government form and the national requirements of special society, and appears in the democratic political system. Such a democratic political system is a powerful tool for carry ing out and implementing rule of law under the social form. Then, more importance is attached to the realization of purpose value of democracy. Equity is just on the contrary. The absolute equality and the relative equality are the target people pursue. Equality is not 
like democracy that people have the dispute about. It is an eternal value existence recognized by the people in different social form.

The realization of equality is the original intention of various systems, and the legal system is not exceptional. For example, in the early days of China's feudal society, equity was described in "The Analects of Confucius - Ji Shi" that "I heard that the kings owning fief and ministers owning family fief are not worried about the lack of wealth and poverty. Instead, they do worry about mald istribution and unrest. There is no poverty if wealth is rationally distributed; all people live on harmony, then the population will not be reduced; with the society in peace, the country would not be overturned." This is the concept that scholars put forward to administer state affairs well and bring peace to people, reflecting the people's yearning and pursuit of equality. For another example, the American's 1776 "The Declaration of Independence" says: "We hold these truths to be self-evident, that all men are created equal, that they are endowed by their Creator with certain unalienable Rights, that they are among these are Life, Liberty and the pursuit of Happiness." Article II of Universal Declaration of Human Rights" says that "Everyone is entitled to enjoy all the rights and freedoms set out in this declaration, without distinction of race, color, gender, language, religion, political or other opinion, national or social origin, property, birth or any other status." Hereof, equality is a kind of idea, a kind of pursuit. Another idea that can promote the realization of equality is democracy, while being a tool respected by people. But the limitation of this tool just expresses impossible to achieve the whole, absolute equality, and it is limited. When democracy and equality give expression to a tool and a purpose, the time of conflict is often the time to need choice, like the so-called "progressive" democratic electoral system in the west, which is classified in the rank of white and black, or the poor and the rich, or the members of Parliament and civilians and so on. Their rights to vote are different. The inequality of the system itself is not possible to realize the equality of all. For example, when emphasizing "everyone is equal", it is required to cancel the voting method-"The minority is subordinate to the majority". It is clearly not rational in social affairs management, but also not conducive to the stability of the country. Therefore, the choice of instrumental value and purpose value is a difficult problem.

\section{B. The Realization Form of Democracy and the Pursuit of Equality Embody the Contradiction between Reality and Ideal.}

The realization of democracy is more democratic political system. It's most prominent expression is election and vote, then some small groups' democratic system in specific social life. The smaller range, the higher possibility of democracy and equality is also the most easy to be achieved. National conditions need differs. The realization degree of democracy and equality in the socialist and in the capitalist countries is certainly different. China is a country that advocates collectivism for most people, with its collective democracy and equality prior to the individual's needs for democracy and equality, while the equality of capitalism is more focused on the realization of individual freedom or collective freedom, with the state and the collective interests being the next. However, whatever different the form of democratic system is, the people's pursuit of equality is always the highest. If you hope that all aspects of life are equal, it is easy to ignore your own conditions and the limitations of social conditions. Therefore, the existing democratic system is far from reaching the people's pursuit of equality. Further we should not be influenced by the freedom and equality advocated in the western (especially American) and blindly believe that capitalism so-called equality is absolute equality, and should not mix up equality and democracy. The idea that "equality must be expressed in democracy, while democracy must have equal", otherwise, it is false democracy, such understanding is extreme, just considering the individual's needs and interests, ignoring the interests of groups, society and nation. The socialist democracy should be collective democracy, equality is also equality of the vast majority of people. It is more suitable for China's national conditions and development.

\section{THE CAUSE OF CONFLICT BETWEEN DEMOCRACY AND EQUALITY}

There is a reason for the dilemma of democracy and equality. These contradictions should be taken seriously to deal with in combination of the reality.

\section{A. These Conflicts are the Inevitable Result of the Development of China's Contemporary Politics, Economy, Culture and so on}

In practice, the tangible performance of democracy and equality of is right, Marx once pointed out: "Right is never outside the economic structure of society and the cultural development of the society which is restricted by its economic structure."1 That is to say, the setting of right must reflect a nation's current economic development situation and cultural characteristics. In of view of its economic development, these conflicts are different choice of value for equity and democracy made by the people in different economic regions due to imbalanced economic development. For example, the pursuit of material equality sought by farmers in the backward rural areas is higher than that in the pursuit of democratic rights. They certainly select the former when the both are in conflict. Another obvious leading factor is the degree of education, or the so-called degree of civilization. In the regions with relatively higher degree of civilization, people, with a relatively stable, progressive value and value judgment standard, can correctly understand the purpose and significance of the definition to the rights so as to make a correct choice. On the contrary, people, with low level of civilization, can't correctly make use of rights. They often choose some unreasonable or ignorant or illegal way of act, trying to achieve equal status he believes, such as the crime of trafficking in women, just because "buying

\footnotetext{
${ }^{1}$ Marx. Critique of the Gotha Program [A] The Complete Works of Marx and Engels (19th volume) [C]. Beijing: People's Publishing House, 1963
} 
wife", a foolish and illegal thought, created motivation and market for such crimes.

B. Since China and the West Differ in Race, Nation and Culture, They Have Generated Different Values and the World Outlook. As Reflection, the Demand for Democracy and Equality Is Different

Capitalism is highly developed today. The maximum material wealth makes people's demand for equality extend to the field of democratic rights and eager to get real absolute freedom and equality. We are in the developing stage of socialism, and the economy is facing a new transformation and development. Our people are mo re eager for the equality of material life, and then partially for democratic rights they enjoy. The development of democracy and equality in the west is closely related to its traditional religious culture and colonialist culture. The Chinese Confucian culture is the core traditional culture in China. Also China has some regional, national special cultural inheritance and virtue which serve as soil for growing Chinese style democratic and equality. The huge cultural difference has produced a certain difference in world outlook and values. For example, for the death penalty, the Western religious culture hopes to give people the chance of redemption, the long time of custody and repentance. In China, it is stressed that "blood for blood" is fair, that the existence of death penalty is perfectly logical and reasonable. Thus, the democracy and equality desired by the contemporary western countries is totally different with that of the Chinese people in the degree and range.

In addition, the different understanding of equality and democracy by the government and the different ways of democratic system have certainly resulted in the regional differences and stage differences in the development of democracy and equality.

But these as above said do not mean that the conflict between democracy and equality is irreconcilable. To get rid of the thinking dilemma about the rule of law, democracy and equality, the rule of law is an effective tool to reconcile the both.

\section{JUMP OUT OF THE PREDICAMENT OF THINKING, GIVE PLAY TO A RECONCILING ROLE OF THE RULE OF LAW}

\section{A. Jump out of the Predicament of Thinking, Pay Attention to China's Local Culture and National Conditions}

To correctly treat democracy and equality, in the first place, we should respect and pay more attention to the importance played by the Chinese local culture and history in formation of the people's democratic consciousness. The traditional culture in China contains democratic and equal idea more suitable to China.

Some scholars believe that no democracy exists in the traditional culture of China. It is absolute preaching and has violated the Marxism's materialist dialectics and the developing conception of history. Led me compare the orig in of China's democracy and that of the West. The word "democracy" in the western countries derived from the Greek word "demos", meaning people, that is, a state system, within a range of certain class, in accordance with the principle of equality and the minority subject to the majority to commonly manage national affairs. But in ancient, typical democratic Athens, "people" was also circumscribed, and only the citizens could be called the people in this sense. But they were a minority of all the inhabitants of Athens. Not only the slaves and the Gentiles but also their wives and children were excluded2. Such democracy is contrary to the concept of the contemporary bourgeois democracy. If it can be seen as democracy, then can "the people-oriented "concept in the Chinese feudal society be regarded as the original Chinese-style democracy? This is a question worthy of thinking. If the class theory is not used, then the peopleoriented and the people's livelihood in the Chinese feudal society should also be a kind of democracy, only its scope is smaller and its form is simpler.

In the context of the rule of law, democracy is an important symbol of the rule of law. Building a socialist rule of law by copying the concept of Western democracy must violate the construction goal of the socialist rule of law, and will be excluded. The democratic ideas should be of Chinese characteristics. Its main body should be clear and its direction should be clear. It can provide support to the development of socialist rule of law.

In addition, equality, the concept closely linked with the rule of law, also encountered such a dilemma: a rapid completion of the construction of the socialist rule of law could achieve real equality. Therefore, some scholars put forward transplanting the western democracy and system and the idea of rule of law could rapidly obtain the rule of law. The practice has proved that the equality that the western developed capitalist countries have appealed to the whole world so far is not absolute equality in the true sense, but relative equality, an individual equality lagging behind the collective equality concept. Just as "equality of democracy" proposed by Raw, the equality normal form is modified and defined by the meaning of "democracy" of the system concept, while other equality normal forms are modified and defined by specific opportunity, resources, ability or right 3 . The Rawls equality concept has gone beyond the "natural liberty" and "free equality", and is a kind of new interpretation of equality, with constitutionalism democracy as its basis. Our equality should also have a big background that is our socialist legal construction.

\section{B. Give Play to A Reconciling Role of the Rule of Law}

The rule of law can play a role in reconciliation to solve the conflict between democracy and equality, because authorizing limited rights though law is the most authoritative and effective way at present.

Some scholars believe that democracy originated from the pursuit of freedom. "Freedom" firstly appeared in the field of private rights and had very small conflict with democracy. But when it was developed in the public domain,

2 Han Shuifa The Concept of Democracy. Tianjin Social Sciences (Political Philosophy) edition, 2007, (05)

${ }^{3}$ Wang Li. The True Meaning of "Equality of Democracy" of Rawls. Social Science Research, 2010, (01) 
the contradiction between democracy and freedom was more serious. At this time, the individual's freedom in the public affairs was expressed in the owning of management authority, which in a relatively small range was called autonomy, but in the modern country namely was called democracy4. De mocracy, as a tool for governing the country, is not contradictory to the instrumental value of the law, but in line with the law. A mong democracy and law, one of the key integrating points is that law should be the guarantee of democracy, while democracy is the foundation of law's emergence, implementation and function. Second, as a way of administering a country and a mode of life, the rule of law needs a democratic system.

Accordingly, equality and the rule of law also have a relationship which can't be separated. "In the end of historical evolution, no matter how equality is disorganized and lacks contents, equality is always the soul of rules, and a law of various laws. It is a legal right, an only one legal right." 5 This expresses that equality is the soul of the rule of law, regardless of race or nationality, the right of equality as a basic right for human being survival has been widely recognized.

Whereas democracy, equality and the rule of law are closely linked, there are two approaches for playing the role of the rule of law: first, through the perfect legal system to standardize the democratic rights and equal rights; second, establish a good, civilized thought and consciousness of rule of law and get rid of non rational understanding of democracy and equality from the mind of the people.

The first approach can is to be effective immediately, specific, operational. Through the direct formu lation of laws and regulations, we set up the corresponding democratic rights and obligations and equal rights and obligations which act directly on social practice, and authorize judicial authority, administrative law enforcement departments to monitor and regulate them within the scope of duty.

The second approach is a long process. Along with the development of the rule of law, citizens' awareness of the rule of law will be improved, and the rule of law thinking will gradually take form. Once a good rule of law environment is established, the degree of citizen's faith in law will be improved, and the authority and effectiveness of the law will also be improved. Citizens democratic rights in the management of social and public affairs and the fundamental person equal right will also be protected more. The development of rule of law in any countries can't be made only on the realization of democratic political system. The rule of law, as a kind of life style, must be like a person. When the soul is attached to the body, it can make the body react to the environment flexible, sense the surrounding changes and make the body more colorful. When the rule of law can only become a part of the whole social soul, it can really play its standardizing role, guiding role and education

\footnotetext{
${ }^{4}$ Wang Jianlong. On the Tension of the Concept of Freedom, Democracy and Freedom \& Its Misunderstanding in Modern China. Fujian Forum Humanities and Social Sciences, 2010, (02).

5 [France] Pierre Lepp. On the Equality [M]. Translated by Wang Yundao. Beijing: The Commercial Press, 1991, 5
}

role and so on, in order to achieve good benefits in common social development.

These two approaches in the current practice in China are faced by the impact of the Western thought of the rule of law, democracy and equality. As legislators, judicial person and person with administrative right should become the forerunner for breaking the Western thought shackles, give citizens the right guidance, eliminate the false and retain the truth, selectively review these thoughts, establish the framework of democracy and equality required by China's society and its people and promote the construction of socialist rule of law.

\section{CONCLUSION}

Democracy, equality and the rule of law is a set of indivisible ideas, although there are conflicts and inconsistent among them. But they are based on mutual support and mutual guarantee. Taking China's national conditions and needs into consideration, we shall formulate a correct democratic political system and legal system, promote the progress of the rule of law, use the social effect and strength of the rule of law, promote the overall balanced social development and promote the realization of equality to the greatest extent and within the maximum range.

\section{REFERENCES}

[1] Han Shuifa The Concept of Democracy. Tianjin Social Sciences (Political Philosophy) edition, 2007, (05)

[2] Wang Li. The True Meaning of "Equality of Democracy" of Rawls. Social Science Research, 2010, (01)

[3] Marx. Critique of the Gotha Program [A] The Complete Works of Marx and Engels (19th volume) [C]. Beijing: People's Publishing House, 1963

[4] Wang Jianlong. On the Tension of the Concept of Freedom, Democracy and Freedom \& Its Misunderstanding in Modern China Fujian Forum - Humanit ies and Social Sciences, 2010, (02).

[5] [France] Pierre Lepp. On the Equality [M]. Translated by Wang Yundao. Beijing: The Commercial Press, 1991, 5 